\title{
Who Protects Physicians and Patients from Guidelines?
}

\author{
Martin Wehling \\ Medical Faculty Mannheim, Ruprecht-Karls-University of Heidelberg, Mannheim, Germany
}

Medical guidelines are typically generated by medical associations to guide physicians through the jungle of biomedical knowledge, empirics and opinions. They are normative and, often, particularly in Europe, are regarded as binding for physicians; thus, in law courts, they are highly influential documents. However, according to good medical practice, guidelines should not be applied without a critical assessment of the individual case. Though an existing guideline may seem easily applicable, doctors are under obligation to search for the special features of the patient and to act accordingly which may suggest a deviation from the guideline. Nonetheless, in daily practice guidelines often are regarded as if they were laws; during basic and advanced medical education adherence to guidelines is a major objective.

What if specific guidelines do not reflect rigorous or complete scientific data, as is often the case? Many guidelines are putatively based on the 'level of evidence C', which is essentially the absence of strong evidence and, thus, are largely the product of the inferences and opinions of the writers.

This question was triggered once again by a recent event. The new antiarrhythmic drug, dronedarone, became part of the new guidelines for the treatment of atrial fibrillation by the European Society of Cardiology (Au-
(C) 2012 S. Karger AG, Basel

0008-6312/12/1211-0056\$38.00/0

Fax +41613061234

E-Mail karger@karger.ch

www.karger.com
Accessible online at: www.karger.com/crd gust 2010); its position in the guideline is very prominent [1]. The development of this new guideline must have started in close temporal relationship to dronedarone's EU market approval in November 2009, given the usual time requirements for the completion of such work.

The explicit positioning of the compound in the new guideline resulted in an increased rate of prescription. However, complaints by physicians and patients about side effects and a relatively low efficacy accumulated rapidly. In January 2011, a public letter (a 'Dear Doctor letter') to all German physicians warned of serious hepatotoxicity necessitating liver transplantation. On July 7 , 2011, the drug's manufacturer reported that a large phase IIIb study (PALLAS) in patients with atrial fibrillation had to be prematurely stopped as dronedarone had caused a significant increase of cardiovascular events such as stroke or myocardial infarction versus placebo [2]. The manufacturer pointed out that in PALLAS, patients with permanent atrial fibrillation were included, whereas in ATHENA, which was the pivotal trial leading to market approval, only patients with nonpermanent atrial fibrillation were included. In the interim, the full paper has

A German version of this paper was published in December 2011 [8].

Prof. Martin Wehling, MD

Medical Faculty Mannheim

Ruprecht-Karls-University of Heidelberg, Maybachstrasse 14

DE-68169 Mannheim (Germany)

Tel. +49621 383 9631, E-Mail christine.schummer@medma.uni-heidelberg.de 
been published [3] and results seem even worse than those initially reported, including a significant doubling of mortality from any cause.

It is obvious that guidelines have to reflect actual developments and novel data; however, here it appears that the guideline was hastily changed on the basis of a single study (ATHENA) before this compound was more extensively tested. Yet it has to be acknowledged that ATHENA was the largest trial ever to scrutinize an antiarrhythmic drug in atrial fibrillation, and the immediate conclusions for the population studied were not revoked. Recently, French health authorities concluded that the efficiency of dronedarone was 'insufficient'; this decision was published before the news on PALLAS [4]. It also reflects the opinions of expert critics on the design of ATHENA and the safety of the compound.

The recent finalization of dronedarone's assessment by the European Medicine Agency is completely in line with the negative judgment described above [5]; in consequence, the manufacturer changed the labeling information and restricted the use of dronedarone to cases for whom alternative means of treatment have failed (see the 'Dear Doctor Letter', September 2011).

This case is an excellent example of a premature guideline change which caused considerable discomfort in the medical community. Although other explanations are also likely to have been involved, the guideline decision could support the until-now unsubstantiated belief that key opinion leaders contributing to this change may have been biased, even if unintentionally.

This is also not a solitary case: the platelet inhibitor ticagrelor was included in the new European guidelines on myocardial revascularization before it was approved in the European Union [6]. The guideline change and market approval were based on a single large trial, PLATO. For this trial, however, an inconsistency regarding the geographical distribution of results has become known [7]: in Poland and Hungary, significant superiority over clopidogrel was observed, whereas ticagrelor was inferior to this compound in the US (despite this, it was recently approved by the FDA). The producer performed the monitoring of the study in Poland and Hungary, while in the US this was done by an independent CRO.

This is another example of how in the context of our accelerated and hasty pace of incorporation of medical 'innovation', guidelines may be changed before important questions have been answered. It is obvious that physicians and patients become unsettled by such developments and that physicians are heavily burdened by the obligation to critically examine guidelines. This is partially due to the fact that, in Europe, healthcare systems normally do not pay for more than 5- to 10-minute contacts between physicians and patients. One of the coping strategies to respond to this time limitation is to employ guidelines as 'cookbook recipes' to speed evaluation and management.

This dilemma does not allow for complacency: even if in the areas with 'solid data' major questions remain unanswered, a very basic problem of the guideline concept has also to be acknowledged and properly dealt with. Doctors and lawyers tend to overestimate the normative value of guidelines; they should become more conscious about these limitations and should encourage careful evaluation of the applicability of the unmodified guideline to the individual patient. In addition, a delay of duration appropriate to the individual case in finalizing a guideline involving a new drug should be regularly considered if the database is generally acknowledged to be limited. The guideline should be more tentative and should encourage tailoring or even negating application to an individual patient when the physician's judgment suggests that this is appropriate.

\section{Conflict of Interest}

The author was employed by AstraZeneca R\&D, Mölndal as director of discovery medicine (i.e. translational medicine) from 2004 to 2006 while on sabbatical leave from his professorship at the University of Heidelberg. After his return to this position in January 2007, he received lecturing and consulting fees from Novartis, Takeda, Roche, Pfizer, Bristol-Myers, Daichii-Sankyo, Lilly and Novo-Nordisk.
References

Who Protects Physicians and Patients from Guidelines?
European Heart Rhythm Association, European Association for Cardio-Thoracic Surgery, Camm AJ, Kirchhof P, Lip GY, Schotten U, Savelieva I, Ernst S, Van Gelder IC, AlAttar N, Hindricks G, Prendergast B, Heidbuchel H, Alfieri O, Angelini A, Atar D, Colonna P, De Caterina R, De Sutter J, Goette
A, Gorenek B, Heldal M, Hohloser SH, Kolh P, Le Heuzey JY, Ponikowski P, Rutten FH: Guidelines for the management of atrial fibrillation: the Task Force for the Management of Atrial Fibrillation of the European Society of Cardiology (ESC). Eur Heart J 2010;31:2369-2429. 
2 Sanofi Provides Multaq ${ }^{\circledR}$ Phase IIIb PALLAS Trial Update. http://en.sanofi.com/binaries/20110707_PALLAS_en_tcm28-33021. pdf (accessed July 26, 2011).

-3 Connolly SJ, Camm JA, Halperin JL, Joyner C, Alings M, Amerena J, Atar D, Avezum A, Blomström P, Borggrefe M, Budaj A, Chen SA, Ching CK, Commerford P, Dans A, Davy JM, Delacrétaz E, Di Pasquale G, Diaz R, Dorian P, Flaker G, Golitsyn S, GonzalezHermosillo A, Granger CB, Heidbüchel H, Kautzner J, Kim JS, Lanas F, Lewis BS, Merino JL, Morillo C, Murin J, Narasimhan C, Paolasso E, Parkhomenko A, Peters NS, Sim KH, Stiles MK, Tanomsup S, Toivonen L, Tomcsányi J, Torp-Pedersen C, Tse HF, Vardas P, Vinereanu D, Xavier D, Zhu J, Zhu JR,
Baret-Cormel L, Weinling E, Staiger C, Yusuf S, Chrolavicius S, Afzal R, Hohnloser SH, the PALLAS Investigators: Dronedarone in high-risk permanent atrial fibrillation. N Engl J Med 2011;365:2268-2276.

4 Multaq: vers la fin du remboursement. http:// www.liberation.fr/societe/01012344984multaq-vers-la-fin-du-remboursement (accessed July 26, 2011).

5 EMA press release of September 22, 2011. http://www.ifap.de/fileadmin/user_upload/ AMTS-Nachrichten/20110922_EMA restricting-use-of-Multaq-dronedarone.pdf (accessed September 26, 2011).

6 European Association for Percutaneous Cardiovascular Interventions, Wijns W, Kolh P, Danchin N, Di Mario C, Falk V, Folliguet T,
Garg S, Huber K, James S, Knuuti J, LopezSendon J, Marco J, Menicanti L, Ostojic M, Piepoli MF, Pirlet C, Pomar JL, Reifart N, Ribichini FL, Schalij MJ, Sergeant P, Serruys PW, Silber S, Sousa Uva M, Taggart D: Guidelines on myocardial revascularization: the Task Force on Myocardial Revascularization of the European Society of Cardiology (ESC) and the European Association for Cardio-Thoracic Surgery (EACTS). Eur Heart J 2010;31:2501-2555.

7 Serebruany VL: Aspirin dose and ticagrelor benefit in PLATO: fact or fiction? Cardiology 2010;117:280-283.

8 Wehling M: Who protects physicians and patients from guidelines? (in German). Dtsch Med Wochenschr 2011;136: 2560-2561. 